\title{
Інноваційна діяльність та педагогічна комунікація викладача загальної хірургії
}

\begin{abstract}
У роботі зосереджено увагу на аспектах покращення інтелектуальних здібностей студентів на кафедрі загальної хірургії вищого медичного навчального закладу. Особливістю є вплив самоменеджменту викладача на ефективність робочого процесу майбутніх спеціалістів. Передбачено збільшення продуктивності застосування знань у процесі навчання, що здійснюється шляхом виконання ряду сучасних методів оптимізації навчального процесу студентів. Знання основ менеджменту і самоменеджменту, практика самоменеджменту вдосконалює навички викладача та прискорює темпи формування національної інтелектуальної медичної еліти.
\end{abstract}

Ключові слова: самоменеджмент; ефективність; оптимізація; процес; метод; хірургія; підхід.

Інтеграція у світовий та європейський освітній простір зумовилиа необхідність модернізації вітчизняної системи освіти. Реформування концептуальних, структурних і організаційних засад освітянської системи України вимагає підготовки нового покоління педагогічних кадрів, здатного до роботи в сучасних соціально-економічних умовах.

Завдання викладача вищих навчальних закладів полягає не тільки в передачі знань, а й формуванні особистості майбутнього лікаря. Тому викладацька діяльність потребує сучасного розуміння впровадження інноваційних технологій в організацію навчального процесу.

Актуальність теми дослідження визначається тим, що багато викладачів недостатньо оволоділи навиками сучасного керування навчально-виховним процесом. Тому проблема самоменеджменту викладачів медичних вищих навчальних закладів повністю не вивчена і вимагає більш поглибленого розгляду [1].

Мета роботи: впровадження менеджменту, спрямованого на максимальне використання власних можливостей, свідоме управління власним часом.

Реалії сьогодення зумовлюють переосмислення функцій та результатів медичної освіти, зокрема започаткування інновацій у викладанні дисципліни загальної хірургії у вищих медичних навчальних закладах.

Особливістю викладання $є$ поєднання фахових здібностей викладача і лікаря-хірурга. На наш погляд, самоменеджмент викладача кафедри загальної хірургії пов'язаний із різноманітними комунікаційними стосунками в організаційних структурах університету та лікувальних закладів. Класичний менеджмент передбачає планування, звіт, контроль та корекцію діяльності [2]. Особливості менеджменту в умовах вищого медичного навчального закладу полягають у результативності і ефективності процесу управління, досягнення поставленої цілі. Практика менеджменту базується на фахових знаннях та відповідальності викладача, здатності прийняття рішень щодо подальшого навчання студента та оцінці його спроможності засвоювати передбачений програмою матеріал.

3 точки зору технології управління, менеджмент неможливий без таких якостей, як уміння володіти собою, підтримувати власну продуктивність, правильно використовувати час, враховувати індивідуальні особливості та колективні можливості.

Саме викладач виступає модератором конкретних нововведень. Він має широкі можливостями і необмежене поле науково-педагогічної діяльності, оскільки на практиці переконується в ефективності створених технологій та методик навчання, проводить дослідницьку роботу, залучаючи до наукового пошуку студентів.

Впровадження у навчальний процес сучасних технологій вимагає від викладача спеціальної психолого-педагогічної підготовки, оскільки у професійній діяльності реалізуються як предметні знання, так і сучасні підходи у сфері педагогіки, психології та виховання. Викладачі навчального закладу повинні оволодіти новітніми освітніми технологіями з метою організації процесу власного навчання, підвищення майстерності, професіоналізму, компетентності.

У цьому сенсі пріоритетними напрямами мають бути інформатизація, профілізація, інноваційність, спрямованість на розвиток, гуманістичність, демократичність [6]. 
3 перших днів навчання викладач має прагнути сформувати у студентів досвід роботи щодо організації навчальної праці та всіляко допомогати оволодівати практичними навичками.

Якісний рівень самоменеджменту проявляється через інноваційний характер управлінської праці, спрямованість на зміни, цінність орієнтації в освітній організації та її управлінських підсистемах. Дуже важливою складовою сучасного менеджменту є пошук раціональних шляхів заміни старих схем навчання новими у вищих медичних навчальних закладах.

В умовах інформаційного прогресу стандартний підхід до процесу викладання клінічних дисциплін стає менш ефективним. Найбільшим недоліком традиційного навчання $є$ розрив між теоретичними знаннями студентів та володінням практичними навиками, необхідними для професійної діяльності. Європейська кредитно-модульна система дозволяє усунути наявні недоліки.

Запровадження сучасних технологій забезпечує швидкий динамічний розвиток особистості кожного студента. 3 одного боку, створюємо умови навчання, при яких студент мав би потужну мотивацію до отримання нових знань та умінь. 3 іншого боку, варто посилити його внутрішню активність до засвоєння великого об’єму матеріалу, відповідно здібностям та інтересам. 3 цією метою запроваджено модуль як структурну одиницю робочої навчальної програми із загальної хірургії. Модульне навчання допомагає самостійно працювати із запропонованою індивідуальною навчальною програмою, включає цільовий план дій, банк інформації і методичне керівництво із досягнення поставлених дидактичних цілей. Слід зазначити, що обсяг знань повинен бути відповідним об’єму, якого потребує лікар загальної практики або сімейної медицини, а не спеціаліста вузького медичного профілю.

У процесі викладання започатковуємо і виділяємо найбільш суттєві проблеми та завдання, які доводиться вирішувати лікареві, коли він стикається з хірургічними хворими в повсякденній діяльності.

На практичних заняттях передбачено час для самостійної роботи студентів з пацієнтами, курація яких триває протягом всього періоду навчання на кафедрі.

У процесі особистого спілкування з пацієнтом майбутній лікар під наглядом викладача освоює особливості роботи з хірургічними хворими, відпрацьовує практичні навички та прийоми деонтологічного спілкування. Після закінчення курації пацієнтів детально обговорюються з виклада- чем основні моменти перебігу хвороби, в процесі якого загострюється увага студента на допущені помилки, аналізуються їх причини. В ході такого обговорення у студентів виробляється стійке розуміння своєї причетності до лікувального процесу, що безперечно стимулює особистий ріст. Завершується цей етап написанням історії хвороби і її захистом.

Під час підготовки до чергового заняття студенти, крім основної, більш зацікавлено вивчають додаткову літературу. Такий підхід підвищує особисту мотивацію до поглибленого засвоєння предмета.

Отже, ефективність інноваційної діяльності викладача залежить від правильного самоменеджменту, який охоплює конкретні функції, що перебувають у певній послідовності і взаємозв’язку. Гуманістично зорієнтована та інноваційно спрямована педагогічна діяльність - це творча реалізація самого викладача та його професійне вдосконалення [3].

Зазначимо, що планування - основа підготовки до реалізації визначеної мети. План, як чітко визначений на певний термін порядок роботи, доцільно підготувати заздалегідь, щоб звільнити пам’ять від непотрібної інформації [1]. Нотатки плану можна робити у стандартному програмному засобі - персональному інформаційному менеджері Microsoft Office Outlook.

Перед плануванням потрібно зважити розумові та фізичні сили, можливості, оскільки свідома їх оцінка - гарантія реальності плану та запорука його успішної реалізації [2].

Викладач вищого медичного навчального закладу повинен постійно вдосконалювати мистецтво самоменеджменту, в основу якого покладено раціональне планування робочого часу, усунення спілкування, яке відволікає від справ, відведення певного часу для підготовки до занять, усунення перевантаження, підтримання фізичного та психологічного стану здоров’я.

Умовами успіху системи самоменеджменту є: самоорганізація викладачем не тільки власної професійної діяльності, але й повсякденного життя; постійна робота викладача над розширенням кола знань та набуття нових навичок самоменеджменту; введення навчально-освітніх програм із самоменеджменту на курсах підвищення кваліфікації викладачів; використання різноманітних форм навчання викладачів основам самоуправління (спецкурс, семінар-практикум, круглий стіл, ділова гра, тренінг); постійний моніторинг та контроль адміністрацією вищого медичного навчального закладу рівня самоуправління викладачів. 
Наближений до реальної практики самоменеджмент викладача загальної хірургії передбачає адекватну оцінку власної діяльності [4], сприяє самореалізації, розвитку його професійної самосвідомості, розкриттю творчого потенціалу.

Висновки. Професійний рівень сучасних викладачів медичних вищих навчальних закладів повинен відповідати вимогам, які висуває розвиток суспільства, змінам у всіх сферах діяльності

\section{СПИСОК ЛІТЕРАТУРИ}

1. Бойко Я. В. Планування навчальної діяльності студентів вищого навчального закладу // Матеріали Всеукраїнської науково-практичної конференції “Перший крок у науку”. - Луганськ : Поліграфресурс, 2010. - Т. 9. - С. 6-9.

2. Друкер П. Менеджмент / П. Друкер, Д. А. Макьярелло.М. : ООО “И. Д. Вильямс”, 2011.-704 с.

3. Зайверт Л. Ваш час - у ваших руках / Л. Зайверт.- М. : Инфа - М. : Интерексперт, 1995. - 267 с.

4. Козаков В. А. Самостоятельная работа студентов и ее информационно-методическое обеспечение / В. А. Казаков.К. : Вища шк., 1990.- 247 с.

\section{REFERENCES}

1. Boiko, Ya.V. (2010). Planuvannia navchalnoi diialnosti studentiv vyshchoho navchalnoho zakladu [Planning of educational activity of students of higher educational institutions]. Materialy Vseukrainskoi naukovo-praktychnoi konferentsii: Pershyi krok u nauku - Proceedings of the All-Ukrainian Scientific and Practical Conference: The First Step in Science, 9, 6-9 [in Ukrainian].

2. Druker, P., \& Makiarello, D.A. (2011). Menedzhment [Managment]. OOO I. D. Viliams [in Russian].

3. Zaivert, L. (1995). Vash chas - u vashykh rukakh [Your time is in your hands]. Infa, Moscow: Interekspert [in Ukrainian].

4. Kozakov, V.A. (1990). Samostoyatelnaya rabota studentov i ee informatsionno-metodicheskoe obespechenie [Independent work of students and its informational and methodical support]. Kyiv: Vyshcha shkola [in Russian].

5. Lukashevych, M.P. (1999). Teoriia i praktyka samomenedzhmentu. Navch. Posib. [Theory and practice of self-mana- людини та реформуванню системи вищої освіти.

Проблема самоменеджменту потребує подальшого дослідження в напрямку власної професійної діяльності викладача, яка, у свою чергу, впливає на ефективність організації навчального процесу.

Знання основ менеджменту і самоменеджменту сприяє покращенню виконання функційних обов’язків викладача загальної хірургії вищого медичного навчального закладу.

5. Лукашевич М. П. Теорія і практика самоменеджменту : навч. посіб. / М. П. Лукашевич.- К. : МАУП, 1999.- 360 с.

6. Неперервна професійна освіта: теорія і практика // Науково-метод. журн. - К., 2002. - № 3. - С .5-7.

7. Пригодій М. А. Самоменеджмент викладача вищого навчального закладу / М. А. Пригодій // Вісник Чернігівського нац. пед. універс. - 2012. - Серія Педагогічні науки. - Чернігів. - Вип. 97

8. Тимошенко Г. Організація самоменеджменту в процесі підготовки керівника ЗНЗ до управління якістю освіти / Г. Тимошенко // Освіта і управління. - 2007. - Т. 2 . - № 1.

gement. Manual]. Kyiv, MAUP [In Ukrainian].

6. (2002). Neperervna profesiina osvita: teoriia i praktyka [Continuing professional education: Theory and practice]. Naukovo-metod. zhurn. Kyiv - Scientific and Methodological Journal, Kyiv, 3, 5-7 [in Ukrainian].

7. Pryhodii, M.A. (2012). Samomenedzhment vykladacha vyshchoho navchalnoho zakladu [Self-management of a teacher of a higher educational establishment]. Visnyk Chernihivskoho nats. ped.univers. Seriia Pedahohichni nauky, Chernihiv - Herald of Chernihiv National Pedagogical University. Series Pedagogical Sciences, Chernihiv, 97 [in Ukrainian].

8. Tymoshenko, H. (2007). Orhanizatsiia samomenedzhmentu v protsesi pidhotovky kerivnyka ZNO do upravlinnia yakistiu osvity [Organization of self-management in the process of preparation of the head of the IEE for the quality management of education]. Osvita i upravlinnia - Education and Management, 2 (1) [in Ukrainian].

Отримано 01.02.2018

\section{O. I. DRONOV, A. V. PROTSIUK, O. A. SKOMAROVSKII, A. I. GORLACH, T. V. LUBENETS}

O. Bohomolets National Medical University

\section{INNOVATIVE ACTIVITY AND PEDAGOGICAL COMMUNICATION OF A LECTURER OF GENERAL SURGERY}

The authors focused on the aspects of the students' intellectual abilities improvement of the general surgery department at the medical educational institution. The special feature is the impact of the teacher's self-management on the working process effectiveness of the future specialists. The authors have provided the knowledge productivity increase in the learning process with the help of a number of modern methods of educational process optimization by students. Knowledge of bases of management and self-management, the practice of self-management improves the teacher's skills and speeding up the formation of the national intellectual medical elite.

Key words: self-management; efficiency; optimization; process; method; surgery; approach. 